DOI: $10.2478 / \mathrm{v} 10014-010-0010-4$

Agrovoc descriptors: insect nematodes, laboratory experimentation,efficiency,biological control,oulema melanopus, pest control,pests of plants,plant protection,application rates

Agris category code: $\mathrm{H} 10$

\title{
Activity of entomopathogenic nematodes (Rhabditida) against cereal leaf beetle (Oulema melanopus [L.], Coleoptera, Chrysomelidae) adults under laboratory conditions
}

\author{
Žiga LAZNIK ${ }^{1}$, Melita ŠTRUKELJ ${ }^{2}$, Stanislav TRDAN ${ }^{3}$
}

Received December 16, 2009, accepted June 7, 2010.

Delo je prispelo 16. decembra 2009; sprejeto 7. junija 2010.

\begin{abstract}
In 2009, three Slovenian strains of entomopathogenic nematodes) and commercial product Entonem (active ingredient $S$. feltiae), were tested under laboratory conditions for their activity against adult cereal leaf beetles (Oulema melanopus). The nematode strains were tested at four different doses $(250,500,1000$, and 2000 infective juveniles/adult $)$ and at three temperatures $\left(15,20\right.$, and $\left.25^{\circ} \mathrm{C}\right)$. Steinernema carpocapsae strain $\mathrm{C} 101$ was the most effective and showed itself to be a good alternative to chemical insecticides, and appears to have the highest potential for controlling overwintered cereal leaf beetles under field conditions. In our bioassay the temperature had the greatest influence on the efficacy of the entomopathogenic nematode strains; both $S$. feltiae treatments (strain $\mathrm{B} 30$ and Entonem) proved to work better at the lowest temperature, however the strain $H$. bacteriophora D54 had its best efficacy at the highest temperature in the experiment. Several species (S. feltiae and $S$. carpocapsae) have been efficient at lower suspension concentrations, which enables their economical usage against the cereal leaf beetle in integrated cereal production in the future.
\end{abstract}

Key words: entomopathogenic nematodes, Oulema melanopus, biological control, laboratory experiment

\section{IZVLEČEK}

DELOVANJE ENTOMOPATOGENIH OGORČIC (Rhabditida) NA ODRASLE OSEBKE RDEČEGA ŽITNEGA STRGAČA (Oulema melanopus [L.], Coleoptera, Chrysomelidae) V LABORATORIJSKIH RAZMERAH

V letu 2009 smo v laboratorijskem poskusu preizkušali učinkovitost treh domačih ras entomopatogenih ogorčic in komercialnega pripravka Entonem (aktivna snov S. feltiae) zoper odrasle osebke rdečega žitnega strgača (Oulema melanopus). Delovanje entomopatogenih ogorčic smo preizkušali pri štirih različnih koncentracijah $(250,500,1000$ in 2000 infektivnih ličink/osebek) in treh različnih temperaturah $\left(15,20\right.$ in $\left.25^{\circ} \mathrm{C}\right)$. Rasa $\mathrm{C} 101$ vrste Steinernema carpocapsae je bila najbolj učinkovita in bi lahko predstavljala dobro alternativo kemičnim insekticidom pri zatiranju prezimljenih odraslih osebkov rdečega žitnega strgača na prostem. V našem poskusu je imela največji vpliv na delovanje entomopatogenih ogorčic temperatura; obe obravnavanji z vrsto S. feltiae (rasa B30 in Entonem) sta bili učinkoviti tudi pri nižjih temperaturah, rasa D54 vrste $H$. bacteriophora pa je najbolje delovala pri najvišji temperaturi $\mathrm{v}$ poskusu. Ogorčici S. feltiae in S. carpocapsae sta zadovoljivo učinkovali tudi pri nižji koncentraciji suspenzije ogorčic, kar omogoča večjo gospodarnost rabo njihove uporabe pri zatiranju odraslih osebkov rdečega žitnega strgača $\mathrm{v}$ integrirani pridelavi žit $\mathrm{v}$ prihodnje.

Key words: entomopatogene ogorčice, Oulema melanopus, biotično varstvo, laboratorijski poskus

\footnotetext{
1 Young researcher, B. Sc., University of Ljubljana, Biotechnical Faculty, Dept. of Agronomy, Chair of Phytomedicine, Agricultural Engineering, Crop Production, Grassland and Pasture Management, Jamnikarjeva 101, SI-1111 Ljubljana, e-mail: ziga.laznik@bf.uni-lj.si

2 B. Sc., ibid.

3 Assoc. Prof., Ph. D., ibid.
} 


\section{INTRODUCTION}

In Central Europe seven chrysomelid beetles belong to the genus Oulema (Chrysomelidae family). Two of them, the cereal leaf beetle (CLB), Oulema melanopus (L.) and O. gallaeciana (Heyden), are pests of various cereals (Ulrich et al. 2004). The CLB is spread across Europe, the Middle East and Asia and in North America (Haynes and Gage, 1981; Olfert et al. 2004). The life history and biology of CLB is well known (Casagrande et al., 1977). The adults hibernate gregariously in the soil, such as in field debris, in the crevices of tree bark, or inside rolled leaves (Casagrande et al., 1977). The adults become active in the spring, when temperature reaches $10{ }^{\circ} \mathrm{C}$, and feed initially on wild grasses. Oviposition begins about 14 days after adults resume activity in the spring. During the following two months each female lays several hundred eggs. The larvae pass through four instars, each lasting two to three days. Pupation occurs in the soil up to five $\mathrm{cm}$ beneath the surface. The species are univoltine. Adults feed but become less and less active during the summer and early autumn. The larvae and adults feed on the upper layer of green mesophyll cells, down to the cuticle, staying between the leaf veins (Ulrich et al., 2004). This feeding pattern is characteristic of the CLB and is one way of detecting its presence (Campbell et al., 1989).

The economic impact of the CLB can be significant. Heyer (1977) estimated that a single larva reduces assimilation by about $10 \%$. A massive attack of larvae reduces total assimilation by up to $80 \%$ (Grala et al., 1991) causing losses of about one tonne of grain per ha. Previous studies recommended an economic threshold of one larva per stem (Haynes and Gage, 1981), but this infestation level often results in unacceptably high levels of defoliation (Buntin et al., 2004). More recent studies have suggested a much lower economic threshold (Herbert and van Duyn, 1999). Pre-harvest efforts to control CLB are primarily based on the release of natural enemies; the most successful have been the egg parasite Anaphes flavipes (Foerster) (Maltby et al., 1971) and the larval parasitoid Tetrastichus julis (Walker) (Haeselbarth, 1989).
The application of entomopathogenic nematodes (EPNs) as biological control agents in protected environments is well documented (Kaya and Gaugler, 1993). EPNs carry species specific symbiotic bacteria which, after nematodes infect insect hosts, are released into the hemolymph of the host (Gaugler, 2002). Only infective juveniles (IJs) are able to infect the insect host (Kaya, 2000). Research has demonstrated that EPNs at high concentrations, together with favourable abiotic factors (high humidity, optimal temperature) can be effective biological control agents of adult chrysomelids (Journey and Ostlie, 2000; Trdan et al., 2008). Recent research has confirmed their efficacy in controlling adult western corn rootworm (Diabrotica virgifera virgifera LeConte) (van der Burgt et al., 1998; Toepfer et al., 2005), flea beetles (Phyllotreta spp.) (Trdan et al., 2008), and the Colorado potato beetle Leptinotarsa decemlineata (Say) (Campos-Herrera and Gutiérrez 2009; Trdan et al., 2009). Since adult CLB are found in protected areas we hypothesize that they should be particularly susceptible to EPN infections.

The aim of our research was to study the activity of entomopathogenic nematodes against the CLB adults, to determine which species of $\operatorname{EPN}(S$. feltiae, $S$. carpocapsae, Heterorhabditis bacteriophora) is the most effective, and to investigate how the effectiveness of EPNs is related to temperature and the nematode concentration. In practice, farmers usually do not control the adult stages of CLB, although it was established in one research study that the most effective treatments were low rates of lambda cyhalothrin when applied early while adults were still laying eggs and before or near $50 \%$ egg hatch (Buntin et al., 2004). With the potential efficacy of entomopathogenic nematodes with regard to CLB adults, we would acquire the results necessary for replacing insecticides with the biological control agents mentioned. The most efficient strain shown by our research would then be suggested for incorporation in a sustainable strategy of cereals production. In this way we would contribute to more environmentally friendly production of cereals.

\section{MATERIALS AND METHODS}

2.1 Entomopathogenic nematodes and the cereal leaf beetle

The investigation was carried out during 2009 in Ljubljana (Biotechnical Faculty, Dept. of Agronomy), Slovenia. The commercial preparation (Entonem) was obtained from Koppert B.V., the Netherlands. The EPNs in this preparation is Steinernema feltiae (Filipjev). Once received, the nematode preparation was stored in the dark in a refrigerator $\left(2-4{ }^{\circ} \mathrm{C}\right)$.
Three Slovenian isolates of EPNs were also included in the experiment. All three strains were isolated from the soil (Laznik et al., 2008; Laznik et al., 2009abc). Two Slovenian species (S. carpocapsae $\mathrm{C} 101$ and H. bacteriophora D54) were tested for the first time in this experiment, while Steinernema feltiae strain $\mathrm{B} 30$ has been proven to very effective in a field experiment against the Colorado potato beetle (Laznik et al., 2009d) and in a laboratory assay against rice weevil (Laznik et al., 2010). All EPN strains were reared 
using late instar larvae of Galleria mellonella (L.) (Bedding and Akhurst, 1975). We used only infective juveniles which were less than 2 weeks old. During the experiment we stored the infective juveniles in a water suspension at $4{ }^{\circ} \mathrm{C}$ in the refrigerator.

CLB adults were collected from a test plot of winter wheat being grown by members of the Biotechnical Faculty in Ljubljana. The CLB were caught in sweep nets in late morning, after the dew had dried. We stored the beetles after catching them in ventilated plastic containers (Trdan et al., 2008) and transported to the laboratory, where they were used for experimental purposes no later than 5 hours later. The adults were of different ages, replicating conditions in practice.

\subsection{Laboratory bioassay}

We tested the efficacy of the EPNs in controlling adults of the CLB by exposing individuals to either $0,250,500,1000$, or $2000 \mathrm{IJ} /$ adult. We determined the number of infective juveniles in a previously prepared unknown concentration of nematode suspension by counting the number of such in droplets $(5 \mu \mathrm{l} \times 5)$ and by diluting (adding tap water solution) or by concentrating (reduction to an adequate volume with the assistance of centrifugation). In this manner we obtained the selected concentrations of nematode suspensions $(0,2500$, 5000,10000 , and $20000 \mathrm{IJ} / \mathrm{ml}$ ).

We used the procedure described of Trdan et al. (2008). We placed 10 adult CLBs on a filter paper in a glass Petri dish (diameter $=9 \mathrm{~cm}$ ) with a fresh leaf of wheat. Each treatment was repeated 10 times for a total of $100 \mathrm{CLB} /$ nematode concentration. The following procedure was performed with a time interval repeated three times. One $\mathrm{ml}$ of each nematode concentration was added to the Petri dish which was then sealed with parafilm to prevent the beetles from escaping. The Petri dishes were put in a rearing chamber (type: RK-900 CH, producer: Kambič Laboratory equipment, Semič, Slovenia) with out light at temperatures of 15,20 , and $25^{\circ} \mathrm{C}$ at a relative humidity of $70 \%$.

The number of dead adult O. melanopus was determined 2, 4, and 6 days after treatment (DAT). The dead individuals were dissected to determine if the nematodes were present. In such a manner we wanted to prove that the insects died due to EPN activity.

\subsection{Statistical analysis}

A multifactor analysis of variance (ANOVA) was conducted to determine the differences in mortality rates (\%) between the adults of O. melanopus reared in 48 different treatments (four strains of EPNs - each with four different concentrations at three different temperatures). Before the analysis, the mean mortality was tested for the homogeneity of treatment variances. Mortality rate data were corrected for control mortality, using Abbott's formula (Abbott, 1925). The arcsine square-root was transformed before this analysis. A StudentNewman-Keuls multiple range test $(P \leq 0.05)$ was used to separate mean differences among the parameters in all the treatments. For the 6 days after treatment (DAT) the values of $\mathrm{LC}_{50}$ and $\mathrm{LC}_{90}$ (the numbers of IJs/adult causing $50 \%$ and $90 \%$ mortality) were estimated, and the overall efficacy of the tested nematodes was determined from this estimates (Trdan et al., 2008) All statistical analyses were performed using Statgraphics Plus for Windows 4.0 (Manugistics, Rockville, MD, USA) and the figures were created with MS Office Excel 2003. The data are presented as untransformed means \pm SE.

\section{RESULTS}

Data on analysis of the pooled results are presented in table 1 .

At $15{ }^{\circ} \mathrm{C}$, the natural (control) mortality of the CLB adults was $0.0 \pm 0.0 \%$ ( 2 DAT), $0.64 \pm 0.35 \%$ (4 DAT) and $9.50 \pm 2.92 \%(6 \mathrm{DAT})$. At $20{ }^{\circ} \mathrm{C}$, the comparable values were $4.82 \pm 2.16 \%$ (2 DAT), $5.66 \pm 2.22 \%$ (4 DAT), and $9.7 \pm 3.97 \%$ (6 DAT). At $25^{\circ} \mathrm{C}$, the natural mortality of the CLB adults was $2.42 \pm 1.51 \%$ (2 DAT), $6.06 \pm 2.55 \%$ (4 DAT) and $35.59 \pm 10.86 \%$ (6 DAT). In all nematode treatments, mortality was greater than in the control treatments and so all of the treatments values could be corrected for the natural mortality.
Two days after treatment, the highest mortality (100\%) was recorded with the $S$. carpocapsae strain C101 kept at 20 and $25^{\circ} \mathrm{C}$ (Table 2), and the lowest with the $H$. bacteriophora strain D54 kept at 15 and $20{ }^{\circ} \mathrm{C}$, where the mortality at all concentrations of the nematode suspension was less than $4 \%$ (Table 2 ). When only $S$. feltiae strains are taken into consideration, at all three temperatures and concentrations of the nematode suspension Entonem (51\%) was more efficient than the Slovenian native strain B30 (34\%). When all strains are considered, the S. carpocapsae strain $\mathrm{C} 101$ has the highest efficacy $(68 \%)$ at the lowest temperature and at all concentrations of the nematode suspension, while only Entonem, at a concentration of $500 \mathrm{IJ} /$ adult, performed equally well (62\%) (Table 2$)$. 
Table 1: ANOVA results for corrected mortality of adults of the cereal leaf beetle

\begin{tabular}{llll}
\hline \multicolumn{1}{c}{ Source } & \multicolumn{2}{c}{$\begin{array}{c}\text { Adults } \\
\text { df }\end{array}$} & \multicolumn{1}{c}{ P } \\
\hline DAT & 1204.29 & 2 & $<0.0001^{*}$ \\
Nematode concentration & 346.56 & 3 & $<0.0001^{*}$ \\
EPN strain & 1398.56 & 3 & $<0.0001^{*}$ \\
Temperature & 233.60 & 2 & $<0.0001^{*}$ \\
Replication in time & 2.17 & 9 & 0.0703 \\
Replication in space & 0.28 & 2 & 0.7590 \\
& & & 0.0051 \\
DAT $\times$ nematode concentration & 5.96 & 6 & $<0.0001^{*}$ \\
DAT $\times$ EPN strain & 86.05 & 6 & $<0.0001^{*}$ \\
DAT $\times$ temperature & 72.62 & 4 & $<0.0001^{*}$ \\
Nematode concentration $\times$ EPN strain & 50.56 & 9 & $<0.0001^{*}$ \\
Nematode concentration $\times$ temperature & 58.57 & 6 & $<0.0001^{*}$ \\
EPN strain $\times$ temperature & 352.40 & 6 & $<0.0001^{*}$ \\
DAT $\times$ nematode concentration $\times$ EPN strain & 8.22 & 18 & $<0.0001^{*}$ \\
DAT $\times$ nematode concentration $\times$ temperature & 8.53 & 12 & $<0.0001^{*}$ \\
DAT $\times$ EPN strain $\times$ temperature & 25.94 & 12 & $<0.0001^{*}$ \\
Nematode concentration $\times$ EPN strain $\times$ temperature & 54.37 & 18 & $<0.0001^{*}$ \\
DAT $\times$ nematode concentration $\times$ EPN strain $\times$ temperature & 5.0 & 36 & \\
\hline
\end{tabular}

* Source of variation significant at $\alpha=0.05$

Four days after treatment, the highest mortality was recorded with Entonem $\left(25^{\circ} \mathrm{C} ; 2000 \mathrm{IJs} /\right.$ adult $)$ and the $S$. carpocapsae strain $\mathrm{C101}$; the latter was the most efficient at all temperatures and concentrations of the nematode suspension (Table 1). The lowest efficacy was observed with the $H$. bacteriophora strain D54 at $15^{\circ} \mathrm{C}$, with less than $20 \%$ efficacy on average (Table 2). Among the $S$. feltiae strains, at all three temperatures and concentrations of the nematode suspension, the efficacy of Entonem (71 $\%$ ) was higher than that of the Slovenian native strain B30 (61 \%). At the lowest temperature the $S$. carpocapsae strain $\mathrm{C} 101$ had the highest efficacy (99\%) of all the observed strains at all concentrations of the nematode suspension. At concentrations of 500 and 2000 IJs/adult at the lowest temperature, the Entonem and the Slovenian strain B30 achieved more than $80 \%$ efficacy (Table 2).

Six days after treatment, the highest mortality was caused with the use of Entonem $\left(25^{\circ} \mathrm{C}, 2000 \mathrm{IJs} /\right.$ adult $)$, the $H$. bacteriophora strain D54 $\left(25^{\circ} \mathrm{C}\right.$, all concentrations of the nematode suspension) and the $S$. carpocapsae strain C101, which caused the death of $100 \%$ of the adults of the CLB at all temperatures and concentrations of the nematode suspension (Table 2). The lowest mortality was observed with the B30 strain, which on average caused the death of $69 \%$ of the beetles. At $15^{\circ} \mathrm{C}$, a mortality rate of more than $90 \%$ was achieved with the S. carpocapsae strain C101 and Entonem, at all suspension concentrations, and with the S. feltiae strain B30 at 250, 500 , and $2000 \mathrm{IJ}$ s/adult, respectively. At the lowest temperature, the commercial and native $S$. feltiae strains performed better than at the higher two temperatures in our laboratory assay (Table 2), on the other hand, the $H$. bacteriophora strain D54 performed its best at the highest temperature $(100 \%)$.

Overall, the nematode treatments were generally more effective at $25^{\circ} \mathrm{C}(74 \%)$ than at $15{ }^{\circ} \mathrm{C}(64 \%)$, and $20^{\circ} \mathrm{C}$ (60\%). Among the observed strains, C101 performed better $(95 \%)$ than the other strains included in the laboratory assay (Entonem 67 \%, B30 54 \%, D54 49\%). Both S. feltiae strains performed better at the lowest temperature (over $70 \%$ ) than at the higher temperatures, where their efficacy was only $54 \%$. At the highest temperature, the strain $H$. bacteriophora D54 performed better $(83 \%)$ than at the lower two temperatures $(39 \%$ and $24 \%$, respectively). At $2000 \mathrm{IJs} /$ adult, all four nematode strains killed over $75 \%$ of the CLB adults. Lower doses caused only from $53 \%$ to $65 \%$ mortality. All concentrations of the nematode suspension performed better at $25^{\circ} \mathrm{C}(74 \%)$ than at $15^{\circ} \mathrm{C}(64 \%)$ and $20{ }^{\circ} \mathrm{C}(60$ $\%)$. At 6 DAT the mortality of the CLB adults was higher (81\%) than for the other two observed days (4 and 2 DAT), where mortality was only $71 \%$ and $48 \%$, respectively.

In our research we also determined $\mathrm{LC}_{50}$ and $\mathrm{LC}_{90}$ values for all four studied strains and at all three temperatures for 6 DAT, all of which are summarized in Table 3 . The results showed that strain $\mathrm{C} 101$ had the lowest $\mathrm{LC}_{50}(2$ DAT at $15^{\circ} \mathrm{C}$ : $561 \mathrm{IJs} /$ adult $)$ and $\mathrm{LC}_{90}\left(2 \mathrm{DAT}\right.$ at $15^{\circ} \mathrm{C}$ : 1398 IJs/adult) values at all three temperatures. The commercial product Entonem had the lowest $\mathrm{LC}_{50}$ and $\mathrm{LC}_{90}$ values at $15^{\circ} \mathrm{C}$ (422 IJs/adult and 884 IJs/adult), while strain D54 reached the lowest values of $\mathrm{LC}_{50}(4$ DAT: 375 IJs/adult) and LC 90 (4 DAT: 875 IJs/adult) at the higher temperatures (Table 3 ). 


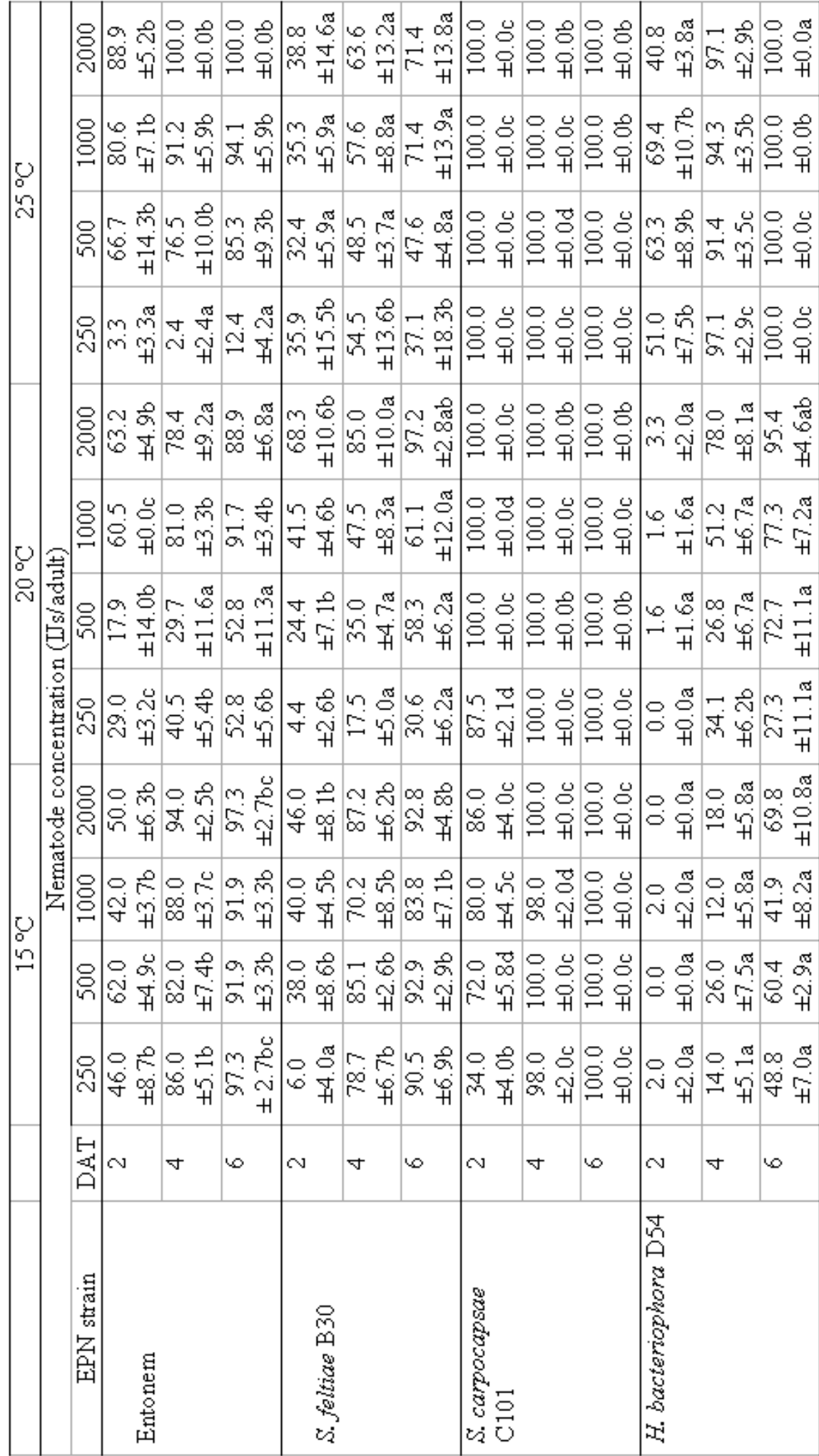


Table 3: The calculated numbers of the nematodes needed to kill $50 \%\left(\mathrm{LC}_{50}\right)$ and $90 \%\left(\mathrm{LC}_{90}\right)$ of Oulema melanopus adults, six days after treatment, at three different temperatures.

\begin{tabular}{|c|c|c|c|c|c|}
\hline & \multirow{2}{*}{$\begin{array}{c}\text { Temp. } \\
\left({ }^{\circ} \mathrm{C}\right)\end{array}$} & \multicolumn{4}{|c|}{ Strain of entomopathogenic nematodes } \\
\cline { 3 - 6 } & 15 & $422(0-2668)$ & $866(0-2011)$ & $\mathrm{C} 101$ & D54 \\
\hline & 20 & $551(207-896)$ & $711(497-924)$ & $-{ }^{(2)}$ & $676(551-1201)$ \\
\cline { 2 - 6 } & 25 & $664(372-955)$ & $877(566-1187)$ & $-(2)$ & $375(0-257-956)$ \\
\hline \multirow{3}{*}{$\mathrm{LC}_{50}{ }^{z}$} & 15 & $884(438-1286)$ & $938(606-1269)$ & $1398(1062-1733)^{(2)}$ & $1347(689-2004)$ \\
\hline & 20 & $1269(946-1592)$ & $1479(1200-1758)$ & $499(70-927)^{(2)}$ & $1257(957-1558)$ \\
\cline { 2 - 6 } & 25 & $1141(868-1414)$ & $1228(786-1671)$ & $-(2)$ & $875(467-1283)^{(4)}$ \\
\hline
\end{tabular}

${ }^{\mathrm{z}} \mathrm{LC}_{50}$ and $\mathrm{LC}_{90}$ expressed as the number of IJs per adult.

${ }^{\mathrm{y}}$ Confidence limits, CL, are given in parentheses

(2) $100 \%$ mortality at 2 DAT

(4) $100 \%$ mortality at 4 DAT

\section{DISCUSSION}

The results of the present research have demonstrated that the mortality of CLB adults is mostly affected by temperature in connection with the concentration of the nematode suspension, different strains, and DAT. All four studied strains (B30, C101, D54, and Entonem) caused the highest mortality of CLB adults 6 days after treatment $(81 \%)$ and the highest concentration of the nematode suspension (78 \%). Among the studied strains, S. carpocapsae C101 showed the best performance, causing a mortality rate of almost $96 \%$ of CLB adults. On the other hand, the only Heterorhabditis nematode in our laboratory bioassay caused an insect mortality of only $49 \%$. In a comparison between $S$. feltiae nematodes, the commercial product Entonem performed better than the native strain B30 (67\% and $54 \%$, respectively).

At 15 and $20{ }^{\circ} \mathrm{C}$, lower mortality was recorded than at $25{ }^{\circ} \mathrm{C}$, thus supporting the results of our previous research studies (Trdan et al., 2006; Trdan et al., 2009) and the research of other groups (Belair et al., 2003; Yang et al., 2003). However both S. feltiae strains performed their best at the lowest temperature, which corresponds to some previous research (Williams and MacDonald, 1995; Trdan et al., 2009), while, on the other hand, the $H$. bacteriophora strain D54 caused the highest mortality at the highest temperature, which was also found in the results of the research of Trdan et al. (2008).

S. carpocapsae C101 performed the best at all three temperatures. Controlling insect pests with foliar application is becoming a more widely-used practice (Broadbent and Olthof, 1995). If this method is required for the control of the first (overwintered) adults of the CLB, the application of $S$. feltiae or $S$. carpocapsae suspensions is recommended, as our research demonstrated that this species showed the highest efficacy in controlling adults at $15^{\circ} \mathrm{C}$. The first adults in the central and south parts of Europe usually appear in the first half of April, when the nights are still relatively fresh in the area in which our research was carried out (Stamenković, 2004).

The higher concentrations proved to be more efficient in our experiment, however all steinernematid species in the present research demonstrated sufficient efficacy also at lower concentration doses. Based on our current findings, we conclude that the activity of EPNs is influenced more by temperature than by the numbers of nematodes applied, but this tends to be species-specific (Arthurs et al., 2004). The minor role of the nematode concentration can be explained by the fact that only a few invasive nematodes need to penetrate an insect host in order to kill it (Bednarek and Nowicki, 1986). Our finding that several species of EPNs demonstrated the same results at lower concentrations as with higher concentrations, gives these biocontrol agents in integrated agriculture better prospects from an economical point of usage, as the cost of plant protection is closely connected to the quantity of the applied EPNs.

However, it is also important to note that results from laboratory tests are not always comparable to field testing (Cantelo and Nickle, 1992) as the functioning of EPNs in the open is influenced by an extensive list of factors. In one relevant study, the $100 \%$ efficacy rate of $S$. carpocapsae in controlling Colorado potato beetle adults, pupae, and larvae in the laboratory manifested as only a $31 \%$ reduction rate in this pest population when the test was repeated outdoors (Stewart et al., 1998). Some further results from studies on the activity of EPNs on other species of beetles (Toepfer et al., 2005; Trdan et al., 2006) have also shown that these agents could be an effective alternative to insecticides. Some 
research has also shown that with proper application techniques and right timing as regards the insect developmental stage, we can reach almost the same results as with the use of insecticides (Schroer et al., 2005). Our current aim is to continue the present research under field conditions as soon as possible. Now that the use of S. feltiae, S. carpocapsae, S. kraussei, and $H$. bacteriophora is allowed in Slovenia - namely, due to the fact that recently all of them became an indigenous species in our country (Laznik et al., 2008; Laznik et al., 2009abc) - there are no longer any legal obstacles to carrying out field experiments with these biological control agents.

\section{ACKNOWLEDGEMENTS}

This work was done within Horticulture No P4-0013, a program funded by the Slovenian Research Agency. Part of the research was funded within Professional
Tasks in the Field of Plant Protection, a program funded by the Ministry of Agriculture, Forestry, and Food of the Republic of Slovenia Phytosanitary Administration.

\section{REFERENCES}

Abbott, W.S. 1925. A method of computing the effectiveness of an insecticide. J. Econ. Entomol. 18: 265-267.

Arthurs, S., Heinz, K.M., Prasifka, J.R. 2004. An analysis of using entomopathogenic nematodes against aboveground pests. Bull. Entomol. Res. 94: 297-306.

Bedding, R.A., Akhurst, R.J. 1975. A simple technique for the detection of insect parasitic rhabditid nematodes in soil. Nematologica 21: 109-110.

Bednarek, A., Nowicki, T. 1986. The effect of intrapopulation factors in the nematodes Steinernema feltiae (Steinernematidae) on the intensity of insect infestation. Zeszyty Problemowe Postepow Nauk Rolniczych 323: 199-212.

Belair, G., Fournier, Y., Dauphinais, N. 2003. The efficacy of steinernematid nematodes against three insect pests of crucifers in Quebec. J. Nematol. 35: 259-265.

Broadbent, A.B., Olthof, T.H.A. 1995. Foliar application of Steinernema carpocapsae (Rhabditida: Steinernematidae) to control Liriomyza trifolii (Diptera: Agromyzidae) larvae in chrysanthemums. Environ. Entomol. 24: 431-435.

Buntin, D.G., Flanders, K.L., Slaughter, R.W., DeLamar, D.Z. 2004. Damage loss assessment and control of the cereal leaf beetle (Coleoptera: Chrysomelidae) in Winter Wheat. J. Econ. Entomol. 97 (2): 374-382.

Campbell, J.M., Sarazin, M.J., Lyons, D.B. 1989. Canadian beetles (Coleoptera) injurious to crops, ornamentals, stored products, and buildings. Agriculture Canada, Research Branch, Publication 1826. 490 pp.

Campos-Herrera, R., Gutiérrez, C. 2009. A laboratory study on the activity of Steinernema feltiae (Rhabditida: Steinernematidae) Rioja strain against horticultural insect pests. J. Pest Sci. 82: 305-209.

Cantelo, W.W., Nickle, W.R. 1992. Susceptibility of prepupae of the Colorado potato beetle (Coleoptera: Chrysomelidae) to entomopathogenic nematodes (Rhabditida: Steinernematidae, Heterorhabditidae). J. Entomol. Sci. 27: 37-43.
Casagrande, R.A., Ruesink, W.G., Haynes, D.L. 1977. The behaviour and survival of adult cereal leaf beetles. Ann. Entomol. Soc. Am. 70: 19-30.

Gaugler, R. 2002. Entomopathogenic Nematology. New Jersey, CABI Publishing: $372 \mathrm{p}$.

Grala, B., Mrówczyński, M., Banaszak, H., Kaniuczak, Z. 1991. Opłacalność chemicznego zwalczania skrzypionek (Lema spp.) występujących na zbożach [Profitability of the chemical control of cereal leaf beetles (Lema spp.)]. Materiały XXXI sesji nauk. Inst. Ochr. Roślin. I.: 161-168 [in Polish].

Haeselbarth, E. 1989. On some parasitic Hymenoptera attacking the cereal leaf beetle Oulema lichenis (Voet) (Coleoptera: Chrysomelidae) in southern Bavaria. J. Appl. Entomol. 107: 493-507.

Haynes, D.L., Gage, S.H. 1981. The cereal leaf beetle in North America. Annul. Rev. Entomol. 26: 259-287.

Herbert, D.A.Jr., van Duyn, J.W. 1999. Cereal leaf beetle: biology and management. Virginia Cooperative Extension System Publ. 444-450.

Heyer, W. 1977. Biologie und Schadwirkung der Getreidehähnchen (Oulema spp.) in der industriemäßigen Getreideproduktion. Nachrbl. Pflanzensch. DDR 31: 167-169.

Journey, A.M., Ostlie, K.R. 2000. Biological Control of Western Corn Rootworm (Coleoptera: Crysomelidae) Using the Entomopathogenic Nematode, Steinernema carpocapsae. Biol. Control. 29: 822-831.

Kaya, H.K. 2000. Entomopathogenic nematodes and their prospects for biological control in California. In: California conference on biological control. Hoddle M.S. (ed). Riverside, California: 38-46 p.

Kaya, H.K., Gaugler, R. 1993. Entomopathogenic nematodes. Annal. Entomol. 38: 181-206.

Laznik, Ž., Tóth, T., Lakatos, T., Trdan, S. 2008. The entomopathogenic nematode Steinernema carpocapsae (Weiser) (Rhabditida: Steinernematidae), a new 
member of Slovenian fauna. Acta Agricult. Slov. 91: 351-359.

Laznik, Ž., Tóth, T., Lakatos, T., Vidrih, M., Trdan, S. 2009a. First record of Steinernema feltiae (Filipjev) (Rhabditida: Steinernematidae) in Slovenia. Helminthologia 46 (2): 135-138.

Laznik, Ž., Tóth, T., Lakatos, T., Vidrih, M., Trdan, S. 2009b. First record of a cold-active entomopathogenic nematode Steinernema kraussei (Steiner) (Rhabditida: Steinernematidae) in Slovenia. Acta Agricult. Slov. 93 (1): 37-42.

Laznik, Ž., Tóth, T., Lakatos, T., Vidrih, M., Trdan, S. 2009c. Heterorhabditis bacteriophora (Poinar) - the first member from the Heterorhabditidae family in Slovenia. Acta. Agricult. Slov. 93 (2): 181-187.

Laznik, Ž., Tóth, T., Lakatos, T., Trdan, S. 2009d. First field experiment with entomopathogenic nematodes in Slovenia. In: Ehlers, R.-U. (ed.). 12th Meeting [of the] "Future research and development in the use of microbial agents and nematodes for biological insect control", Pamplona (Spain), 22-25 June, 200 : IOBC/WPRS Working group "Insect pathogens and insect parasitic nematodes": COST Action 862 "Bacterial toxins for insect control": 361-364.

Laznik, Ž., Tóth, T., Lakatos, T., Vidrih, M., Trdan, S. 2010. The activity of three new strains of Steinernema feltiae against adults of Sitophilus oryzae under laboratory conditions. J. Food. Agric. Environ. 8, 132-136.

Maltby, H.L., Stehr, F.W., Anderson, R.C., Moorehead, G.E., Barton, L.C., Paschke, J.D. 1971. Establishment in the United States of Anaphes flavipes, an egg parasite of the cereal leaf beetle. J. Econ. Entomol. 64: 693-697.

Olfert, O., Weiss, R.M., Woods, S., Philip, H., Dosdall, L. 2004. Potential distribution and relative abundance of an invasive cereal crop pest, Oulema melanopus L. (Coleoptera: Chrysomelidae), in Canada. Can. Entomol.136: 277-287.

Schroer, S., Sulistyanto, D., Ehlers, R.U. 2005. Control of Plutella xylostella using polymer-formulated Steinernema carpocapsae and Bacillus thuringensis in cabbage fields. J. Appl. Nematol. 129 (4): 198-204.

Stamenković, S. 2004. Occurrence and damage of cereal leaf beetle (Oulema melanopus L.). Biljni lekar 32: 124127 [in Serbian].

Stewart, J.G., Boiteau, G., Kimpinski, J. 1998. Management of late-season adults of the Colorado potato beetle
(Coleoptera: Chrysomelidae) with entomopathogenic nematodes. Can. Entomol. 130: 509-514.

Toepfer, S., Gueldenzoph, C., Ehlers, R.-U., Kuhlmann, U. 2005. Screening of entomopathogenic nematodes for virulence against the invasive western corn rootworm, Diabrotica virgifera virgifera (Coleoptera: Chrysomelidae) in Europe. Bull. Entomol. Res. 95: 473-482.

Trdan S., Vidrih M., Valič N. 2006. Activity of four entomopathogenic nematode species against young adults of Sitophilus granarius (Coleoptera: Curculionidae) and Oryzaephilus surinamensis (Coleoptera: Silvanidae) under laboratory conditions. J Plant Dis Protec 113: 168-173

Trdan, S., Vidrih, M., Valič, N., Laznik, Ž. 2008. The impact of entomopathogenic nematodes on adults of Phyllotreta spp. (Coleoptera: Chrysomelidae) under laboratory conditions. Acta Agricult. Scand. B - Soil Plant Sci. 58: 169-175.

Trdan, S., Vidrih, M., Andjus, L., Laznik, Ž. 2009. The activity of four entomopathogenic nematode species against different developmental stages of Colorado potato beetle, Leptinotarsa decemlineata (Coleoptera, Chrysomelidae). Helminthologia 46: 14-20.

Ulrich, W., Czarnecki, A., Kruszyński, T. 2004. The occurrence of pest species of the genus Oulema (Coleoptera: Chrysomelidae) in cereal fields in northern Poland. Electronic Journal of Polish Agricultural Universities, 7 (1): http://www.ejpau.media.pl.

van der Burgt, W.A.C.M., Budai, C., Fodor, A., Lucskai, A. 1998. Parasitism of western corn rootworm adults by Steinernema spp. and Heterorhabditis spp. Proceedings of the Section Experimental and Applied Entomology of the Netherlands Entomological Society 9: $165-170$.

Yang, X., Jian, H., Liu, Z., Yang, H., Yuan, J., Quanli, Z., Shuangyue, L. 2003. Evaluation of entomopathogenic nematodes for control of the beetle, Luperomorpha suturalis Chen (Col., Chrysomelidae). J. Appl. Entomol. 127: 377-382.

Williams, E.C., MacDonald, O.C. 1995. Critical factors required by the nematode Steinernema feltiae for the control of the leafminers Liriomyza huidobrensis, Liriomyza bryoniae and Chromatomyia syngenesiae. Annal. Appl. Biol. 127: 329-341. 